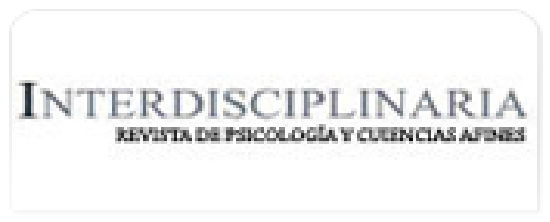

Interdisciplinaria

ISSN: 0325-8203

interdisciplinaria@fibercorp.com.ar

Centro Interamericano de Investigaciones

Psicológicas y Ciencias Afines

Argentina

Castro-Martínez, Jaime A.; Chavarría Roa, Julián; Parra Benítez, Andrés; González, Santiago

Effects of classroom-acoustic change on the attention level of university students

Interdisciplinaria, vol. 33, núm. 2, 2016, pp. 201-214

Centro Interamericano de Investigaciones Psicológicas y Ciencias Afines

Buenos Aires, Argentina

Available in: http://www.redalyc.org/articulo.oa?id=18049289001

How to cite

Complete issue

- More information about this article

Journal's homepage in redalyc.org

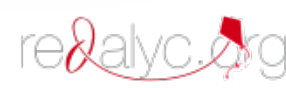

Scientific Information System Network of Scientific Journals from Latin America, the Caribbean, Spain and Portugal Non-profit academic project, developed under the open access initiative 


\title{
EfFEctS OF CLASSROOM-ACOUSTIC CHANGE ON THE ATTENTION LEVEL OF UNIVERSITY STUDENTS*
}

\author{
Jaime A. Castro-Martínez ${ }^{* *}$, Julián Chavarría Roa ${ }^{* * *}$, Andrés Parra Benítez ${ }^{* * *}$, \\ AND SANTIAGO GONZÁLEZ******
}

*University Institution Politecnico Grancolombiano sponsored this project. Project Code 2012-FCS-PEC-BC-394.

${ }^{* *}$ Psychologist. Master in Education. Faculty of Social Sciences. University Institution Politecnico Grancolombiano.

E-Mail: jcastrom@poligran.edu.co

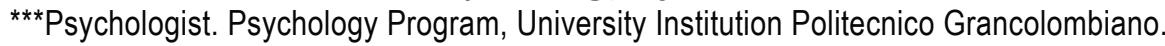

****Psychologist. Psychology Program, University Institution Politecnico Grancolombiano.

${ }^{* * * \star * A u d i o v i s u a l ~ M e d i a ~ P r o f e s s i o n a l . ~ A u d i o v i s u a l ~ M e d i a ~ C e n t e r, ~ U n i v e r s i t y ~ I n s t i t u t i o n ~ P o l i t e c n i c o ~ G r a n c o l o m b i a n o . ~}$ University Institution Politecnico Grancolombiano, CII 57 \#3-00 east, Bogotá - Colombia.

\section{RESUMEN}

Diversas investigaciones han señalado la necesidad de modificar los espacios de aprendizaje para favorecer las condiciones de salud-trabajovida de los docentes y para mejorar las condiciones de aprendizaje de los estudiantes. Dichas modificaciones implican cambios arquitecturales, ya sea a través de amplificadores de sonido o deflectores, que permiten variar los niveles de reverberación del sonido y que por tanto modifican las necesidades de modular la voz y el desgaste asociado en el docente. El objetivo de la investigación realizada fue indagar el efecto del nivel de ruido, de la reverberación y de barreras acústicas, en el nivel atencional de 141 estudiantes de una universidad privada de la ciudad de Bogotá (Colombia). Se utilizaron dos estrategias de medición de la atención. La primera de ellas contó con la medición del nivel atencional a través de un cuestionario con palabras pertenecientes a la clase y no pertenecientes a la misma, pero que tuvieran relación con la asignatura. La segunda estrategia midió el Índice de Atención (IA), el cual estuvo conformado por el promedio de las desviaciones de la mirada a un punto, calculado sobre una cuadrícula. Los resultados señalan diferencias significativas entre los grupos interve- nidos y no intervenidos. Esta diferencia es significativa tanto para la estrategia de medición tradicional de la atención, a través del cuestionario con la lista de palabras, como para la estrategia alternativa de medición del Índice de Atención, a través de la cuadrícula. Este estudio señala que cambios específicos dirigidos a disminuir los valores de reverberación en los salones de clase, afectan positivamente los niveles de atención y el desempeño de estudiantes. Lo que indica la necesidad de mejorar las condiciones acústicas de los sitios de aprendizaje para así lograr tanto mejores comprensiones de los contenidos por parte de los estudiantes como menor desgaste en la voz de los docentes.

Palabras clave: Atención; Ruido; Reverberación; Barreras acústicas; Desempeño de estudiantes.

\section{ABSTRACT}

Noise in learning environments has proven to be a big source of health problems not only for teachers, but also for students. Noise is considered as every type of sound that we are not interested in hearing, whereas a useful sound is the one we want to perceive. Studies that analyze the relation- 
ship between the effects of noise and attention processes are developed within the idea that sound stimulation acts intermittently as an activator and therefore it can generate an over-activation in the individual due to the distortion caused by this diffused stimulation on the attention process. Furthermore, researches also show that the presence of noise affects performance by making subjects focus their attention upon aspects of the task defined as relevant. Researchers have stated the importance of changing learning spaces in order to favor the health- work-life conditions of teachers and to improve the students' learning conditions. These alterations include architectural changes, using sound-field amplification, or ceiling baffles and reflectors that allow changing the reverberation levels of sound in order to modify the need teachers have to modulate their voice and avoid wearing it out. Is common that regulations on the acoustic characteristics of many places set general requisites that are minimal and insufficient to control noise and reverberation, and that are not in line with the guidelines on intermittent sounds.

The objective of this research was to examine the effect of noise, reverberation, and acoustical barriers on the level of attention of 141 students from a private university in. Modular panels with acoustic properties were used for an acoustic intervention in some classrooms, intending to reduce the noise levels. Then, all the students of four courses of Mathematics and Statistics were considered. At least two courses had classes in the classrooms that had the acoustic intervention at the beginning of the semester, and the same teacher should be teaching those courses (in both altered and unaltered classrooms) in order to exclude differences associated with the teacher.

Since the investigation aimed to measure the level of attention of the students that were in both classrooms. We designed two measurement strategies that correspond to the two types of researches that study the relationship between noise and attention. However, this study presents important differences regarding the strategies that are traditionally associated with embedded figures tests, tests regarding global shape processing and details, or surveillance tasks, because these situations were not controlled within a lab but real noise situations in a classroom.
Two strategies of attention measurement were used. The first strategy measured the level of attention through a questionnaire with words belonging and not belonging to the class, but related to the subject. The second strategy allows calculating the Attention Index (AI), which would be measured by the average of the times students look away to a specific point, this is indicated in a grid. The results point towards significant differences between the acoustically intervened and non-intervened groups. That difference is significant both for the traditional attention measurement strategy through a questionnaire with word list and for the alternate Attention Index (AI) measurement strategy using a grid. This study shows that noise levels have an important effect on the students' attention processes, and that specific changes, aimed at decreasing reverberation values in classrooms affect positively the levels of attention and student performance. They also indicate the need to improve the acoustic conditions of learning sites in order to allow students to achieve a better understanding of contents and to lessen the fatigue of the teachers' voices.

Key words: Attention; Noise; Reverberation; Noise barriers; Student performance.

\section{INTRODUCTION}

Noise in learning environments has proven to be a big source of health problems not only for teachers, but also for students (Puyuelo \& Llinás, 1992). The voice is considered one of the most vulnerable aspects among teachers. In addition, dysphonia is one of the most important health issues due to its impact on the personal identity of a teacher, on the expression of emotions, on the communication with others, and on the performance of their professional duties, which are based on their voice (Bureau International D'Audiophonologie BIAP, 2008; Cantor \& Muñoz, 2009a; Escalona, 2006; Tejeda, 2001).

Noise is considered as every type of sound that we are not interested in hearing, whereas a useful sound is the one we want to perceive. 
In order to have a clear perceptual process, it is necessary to extract enough information from the acoustic signal to reconstruct the spoken message. This is why it is necessary to have an excellent ratio between the signal and the noise. The presence of an acoustic masking signal, or of intermittent masking noise, will reduce the information included in the word and for this reason, the hearing perceptual process, as well as the selective-executive attention process, could be changed and the attention will tend to diminish (De Esteban, 2003).

Szalma and Hancock (2011), for example, indicate that speech is an important type of noise. Speech is one of the greatest distracters to which humans are naturally attuned. According to these authors, noise affects the levels of general alertness, activation, and the attentional selectivity. It does not affect working memory performance directly; it affects reaction times in people.

Attention is understood as a vertical control mechanism whose function is to decide the stimuli perceptive resources are going to focus on by activating or inhibiting the processes that elaborate and organize information (Monteoliva, Ison, \& Pattini, 2014). Within an educational environment, attention issues are a meaningful risk factor for scholar failure, which affects academic performance (Barkley, 1997).

Regarding attention, research in Psychology has shown that this process is affected by the level of noise surrounding the subject (Añaños, 1999). Studies that analyze the relationship between the effects of noise and attention processes are developed within the idea that sound stimulation acts intermittently as an activator and therefore it can generate an over-activation in the individual due to the distortion caused by this diffused stimulation on the attention process (Santisteban \& Santa1la, 1990). However, researches also show that the presence of noise affects performance by making subjects focus their attention upon aspects of the task defined as relevant (Santalla \& Alvarado, 1999).

When talking about education, noise control is a matter of great interest due to the need institutions have for creating spaces that facilitate the level of attention of students in order to transfer or build knowledge in an adequate manner (Hernández-Hernández, 1991). Thus, it is known that this soundscape improved attention and learning in students as well as improved vocal health in teachers (FlaggWilliams, Rubin, \& Aquino-Russell, 2011).

The persistence of sound in walls, floors, windows, and ceilings, even after the sound source stops, is a phenomenon known as reverberation (INIFE, 2011). The reverberation time (RT) is the time in seconds required for sound pressure at a specific frequency to decay $60 \mathrm{~dB}$ after the sound source has stopped. Long RTs reduce the clarity of the speech and thereby intelligibility. This is because the speech signals reaching a listener are a mixture of direct energy and time-delayed reflections. In addition, when RTs are too long, undesired sounds (such as moving chairs or scraping feet) remain longer in the room and consequently, noise levels increase (Klatte, Lachmann, \& Meis, 2010). Reverberation is often combined with the teacher's voice, affecting and misleading the attention process of students.

Kennedy, Hodgson, Edgett, Lamb, and Rempel (2006) indicate that the biggest source of noise in a classroom is students and that they strongly interfere with communication when talking or moving around the classroom. The effect of this noise has several consequences among which are: being unable to hear what their peers say, making a greater effort when listening clearly, dealing with distractions, etc.

Shield and Dockrell (2008) and Sato and Bradley (2008) have shown that noise has a detrimental impact upon the cognitive development of children at elementary schools, with older children being more affected even though the classrooms of younger children were noisier.

Some researchers have stated that it is important to change learning spaces in order to favor the health-work-life conditions of teachers and to improve the students' learning conditions (Cantor \& Muñoz, 2009b; Gondim $\&$ Barreto, 2004). These alterations include 
architectural changes, using sound-field amplification (Flagg-Williams et al., 2011; Weil, 2011), or ceiling baffles and reflectors (Dockrell \& Shield, 2006; Yang \& Hodgson, 2007), that allow changing the reverberation levels of sound in order to modify the need teachers have to modulate their voice and avoid wearing it out (Irvine \& Richards, 1998; Möser, Zimmermann \& Ellis, 2009; Wilson, 2005).

It is common that regulations on the acoustic characteristics of many places set general requisites that are minimal and insufficient to control noise and reverberation (Estrada \& Méndez, 2010), and that are not in line with the guidelines on intermittent sounds (Pérez, 2004). These regulations do not get into the technical aspects that are relevant to manage noise and there seems to be little awareness regarding the importance of keeping good acoustic conditions in the learning process.

In Colombia, there are technical regulations to plan and design school environments for hearing comfort. These regulations specify the optimal environmental conditions to guarantee appropriate acoustic improvement (ICONTEC, 2006) and categorize spaces according to sound intensity and reverberation time. They also classify classrooms as a Type A Environment, which should have, at most, between 40 and 45 decibels of sound intensity with a maximum reverberation time from 0.9 to 1 second. It is also recommended for these spaces to have sound absorbing materials that can be located in the highest places of the classrooms - above the 2 meters mark - and on the ceilings (ICONTEC, 2006).

Based on this premise, this research aimed to analyze the effect a particular acoustic change has on the reverberation levels of a specially designed classroom and, at the same time, on the attention levels of students from different majors at a private university in Bogotá (Colombia).

\section{METHOD}

\section{DESIGN AND PARTICIPANTS}

Two designs were used for this research. The first part used a quasi-experimental design with a control group -only with post-testing.
All the students of four courses of Mathematics and Satistics were considered $(n=141$ : 73 men and 68 women; men: 22.4 years old, $S D=2.4$; women: 21.7 years old, $S D=2.6$ ) taking during the early semesters of different majors at a private university in Bogotá. In order to select these courses, several requirements were taken into account: (1) at least two courses had classes in the classrooms that had the acoustic intervention at the beginning of the semester, and (2) the same teacher should be teaching these courses (altered and unaltered classrooms) in order to exclude differences associated with the teacher. The same happened with the course of Statistics.

The second part of the research had an intentional sampling of six students for each one of the four study courses ( 24 students in total, 14 men and 10 women). Selecting this last set of students was performed according to the facilities for analyzing the video recording of the faces of these people. Even though it was a panoramic recording, we selected the students whose facial registration was filmed from beginning to end in the recording.

\section{ACOUSTIC INTERVENTION}

We used modular panels with acoustic properties for the acoustic intervention. These panels were made with a trapezoidal wood structure filled with fiberglass to avoid specular reflections. The material used provided absorption and the diffusion was generated by the prism shape because it prevents sound reflections to use the same incidence angle when returning. These panels also act as lowfrequency resonators due to the distance that separates the material from the wall where it is installed. All this helps to diminish the standing waves. The intervention process consisted on selecting a pilot classroom to install the solution and prove its effectiveness. The space had the specifications established in Figure 1. In order to know the acoustic characteristics of the classroom, we calculated the reverberation time (RT) with a sound level meter, according to the method established in the international normative. The results are shown in Table 1. 


\section{INSTRUMENTS}

To measure the reverberations, we used a portable Phonic PAA3 audio analyzer with a Behringer ECM8000 flat response built-in microphone. This microphone facilitates measurement of SPL, RT60, and 31-band RTA in real time. It also has a spectrum analyzer, an internal generator, EQ setup programming, microphone calibration, and a speaker phase analyzer. VCR Sony DCR-HC2 was used for the filming of faces. To register attentional task was used with a list of words to measure aspects related to the topics of the courses. The task had 30 words, 10 of which were mentioned in class by the teacher and the other 20 were not, but were related to the topics of the class. The answers were selected in a dichotomous way (Yes or No), depending on whether or not the word was mentioned in class. The words used were agreed with the teacher prior to the beginning of the class session.

\section{MEAsuREMENT STRATEGIES}

The investigation aimed to measure the level of attention of the students that were in both classrooms. This is why we designed two measurement strategies that correspond to the two types of researches that study the relationship between noise and attention as stated by Santisteban and Santalla (1990). However, this study presents important differences regarding the strategies that are traditionally associated with embedded figures tests, tests regarding global shape processing and details, or surveillance tasks because these situations were not controlled within a lab but real noise situations in a classroom.

The first strategy measured the level of attention through a questionnaire with words belonging and not belonging to the class, but related to the subject. This strategy follows the classic models of attention measurement of Broadbent (1954). The second strategy allows calculating the level of attention of a group of students selected randomly. The Attention Index (AI) would be measured by the average of the times students look away to a specific point. This is indicated in a grid, where the value of the points located toward the edges is 1 and the value of the ones closer to the center is 5. This average is calculated from the measurement and evaluation of the images of each participant's look, minute per minute, during a 60 -minute recording. All this results in 60 look values per person and their average is taken later on. Two judges were trained to evaluate the looks, and the scores they gave to each participant were validated by correlation. The minimum correlation expected between judges was $r$ higher 0.7 .

\section{Procedure}

Two classrooms with a high level of noise were selected (up $45 \mathrm{~dB}$ ) and the noise measurement was established through a sound level meter (see Table 1). This level of noise should surpass the one established in the local regulation (NTC 4595: ICONTEC, 2006) for the planning and design of school environments for Type A Environments (margin of 40 to $45 \mathrm{~dB}$ ). After selecting two classrooms with the required characteristics, we carried out the acoustic intervention, previously described, in one of them. The results of the acoustic intervention were verified through reverberation time (RT) measurements made with the Phonic PAA3 through the impulsive noise method. This method consists of generating noise with considerable spectral content, with a lot of energy, and a short duration in order to measure the time the sound takes to decrease $60 \mathrm{~dB}$ (see Graphic 1).

After modifying one of the classrooms, we selected two courses (Statistics and Mathematics) belonging to the first semesters of study. We had three sessions with each course: One to familiarize students with the recording and the researchers and the other two to record with the video camera. At the end of each session, we evaluated the level of attention, with the strategies mentioned below, not only in the intervened classroom, but also in the other one in order to avoid having variables related to the teacher. At the end of each session, we administered a task with a list of words that were 
previously selected by the teacher. We asked students for their approval to participate in the study.

\section{STATISTICAL ANALYSIS}

We used several statistical strategies for the analysis, depending on the relationship with the first or second measurement strategy. The continuous variables for each case were described by using central tendency and dispersion indexes.

For the first strategy (word list), we used the Kolmogorov-Smirnov Normality Test. For the second strategy (Attention Index), we used the Shapiro-Wilk Normality Test. In addition, we used the student's $t$-test as the contrast parametric test with every group. As the nonparametric range contrast test, we used MannWhitney $U$ Test. For each case, the comparisons between groups were made keeping into account the variable of the course.

For the reliability test of the AI measurement between evaluators, we used the Pearson correlation coefficient. The comparative analysis of inter-rater reliability showed a value of $r=.79(p<.01)$. We used the quantitative data analysis Program SPSS ${ }^{\circledR}$ version 19.

\section{RESULTS}

\section{SELECTION OF SPACES}

The results of the RT measurement before and after the intervention show differences that can be appreciated in Table 1. By using the procedure of Klatte and collaborators (2010), we carried out three measurements in 3 points, resulting in a time of 2 seconds average reverberation in the unconditioned space and 1.2 in conditioning (see Table 2).

\section{DIFFERENCES BETWEEN GROUPS WITHIN THE SCORES OF THE LIST OF WORDS}

The Kolmogorov-Smirnov normality test indicated non-normality in both group (inter- vened group [I-G] and non-intervened group $[\mathrm{NI}-\mathrm{G}], \mathrm{K}-\mathrm{S}$ test I-G $=.24,<.01 ; \mathrm{K}-\mathrm{S}$ test NI$\mathrm{G}=.30, p<.01)$. The average of correct answers in the word list for the math course in the I-G $(n=40)$ was $8.75(S D=1.46)$ over 10 points, being higher than the average of the NI$\mathrm{G}(n=16)$ (average $=5.50 ; S D=1.75)$. The difference between the means of these groups was significant $(U=52.00 ; p<.01)$ (see Table 3 and Graphic 2).

However, this group also shows differences per gender within the ranges of right answers in word list [Man range $(n=22)=41.61$; Woman range $(n=34)=20.01)]$. A chi square test, which establishes the frequency difference per group allocation and gender, shows significant differences $\left(x^{2}=14.49, p<.05\right)$. We found that due to the intentional allocation of the sample, the group that was not intervened was composed only of women.

To complement this analysis, we carried out an inter-group comparison with the statistics course (see Table 3). The Kolmogorov-Smirnov normality test indicated non-normality in both group $(K-S$ test $\mathrm{I}-\mathrm{G}=.41, p<.01 ; K-S$ test $\mathrm{NI}-\mathrm{G}=.16, p<.01)$. Once again, we found differences between the means of the two group $[I-G$ mean $(n=31)=9.42 ; N I-G$ mean $(n=54)=8.00]$. The difference between these means was significant $(U=391.5 ; p<.01)$. We did not find differences per gender within the test results $(U=699 ; p>.05)$ nor differences in the frequencies between gender and group $\left(\chi^{2}=2.74 ; p>.05\right)$.

\section{Differences between bOth AtTention Index} (AI) SCORES - (THE GRID STRATEGY)

The Shapiro-Wilk normality test indicated the normality of this group of data $(S-W$ test $I-G=.90, p>.05 ; S-W$ test $N I-G=.97$, $p>.05)$. Taking into account the average of the scores given by the two judges, the index of attention for the intervened group $(n=12)$ was $3.33(S D=.52)$ and for the other group $(n=12)$ was $2.92(S D=.42)$. The analysis of the differences in the average score of each group was significant $(t=2.12 ; p<.05)$ (see Table 4 and Graphic 3 ). In order to discard 
variables tied to the course, we compared the average of both courses with the student's $t$-test and there were not substantial differences between them $(t=-.56 ; p>.05)$.

\section{GeNERAL ANALYSIS}

The mentioned results point towards significant differences between the acoustically intervened and non-intervened groups. That difference is significant both for the traditional attention measurement strategy through a questionnaire with word list and for the alternate Attention Index (AI) measurement strategy using a grid.

\section{Discussion}

From the findings previously mentioned it could be concluded that noise levels )understanding noise as the sound we are not interested in hearing and that affects the capture of the information contained in the word) have an important effect on the students' attention processes. These changes in attention seem directly affect the student's performance at identifying words mentioned during class sessions.

These findings would seem to confirm what Santisteban and Santalla (1990) said in the studies on noise and attention, in the sense that acoustical stimulation seems to act in an inter- mittent way as an activator, generating an overactivation in the individual, altering their performance indexes and negatively influencing the performance of the subjects. At the same time, it confirms what Escalona (2006) and Yang and Hodgson (2007) pointed, regarding the need to shorten the reverberation time as a control measure of acoustics in the classrooms, in order to improve the intelligibility in those spaces.

Found data points at the need to modify the learning spaces so the reverberation level in classrooms is diminished. Given that, it is considered pertinent to take into account the local recommendations regarding noise intensity and reverberation time in classrooms, which must be optimal for educational spaces. Some researchers suggest increasing the signal to noise ratio within the classroom by about 15 dB (Escalona, 2006).

Future studies imply the improvement of the conditions of group allocation in order not to have the same partial findings of the word list in the math course. It is also important to enhance the samples of intervened and nonintervened groups. The authors point at the need, in future research, to extend the research sample to other higher education institutions in the country in order to validate the results found here. It is also important to carry out future studies that allow comparisons between local legislations regarding noise and reverberation control within classrooms. 
FIGURE 1

DIMENSIONS OF THE SPACE USED IN THE PILOT CLASSROOM
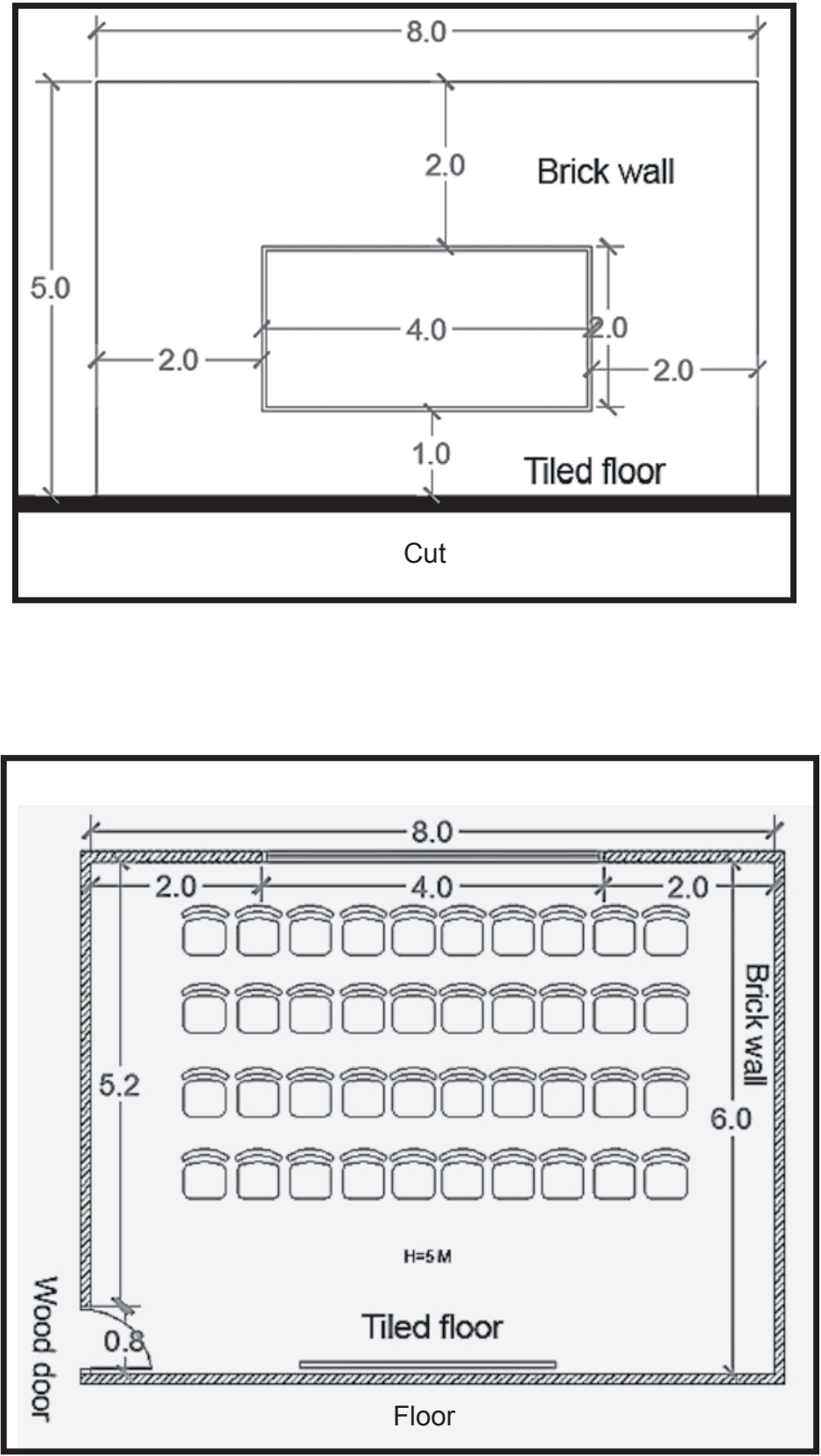
TABLE 1

Results of the Acoustic Measurement before and after the InTERVEntion

\begin{tabular}{|c|cccccc}
\hline Frequency $(\mathrm{Hz})$ & 125 & 250 & 500 & 1000 & 2000 & 4000 \\
\hline RT with No Conditioning & 2.09 & 2.10 & 1.70 & 1.49 & 1.58 & .80 \\
RT with Conditioning & 1.74 & 1.50 & .94 & .80 & .78 \\
\hline
\end{tabular}

TABLE 2

Reverberation Time in seconds Within the Two Learning Spaces

\begin{tabular}{|c|c|c|}
\hline Point / Space & Without Adjustment & With Adjustment \\
\hline Point 1 & 2.1 & 1.2 \\
Point 2 & 2.0 & 1.3 \\
Point 3 & 1.9 & 1.2 \\
\hline Average & 2.0 & 1.2 \\
\hline
\end{tabular}

Source: Own construction 


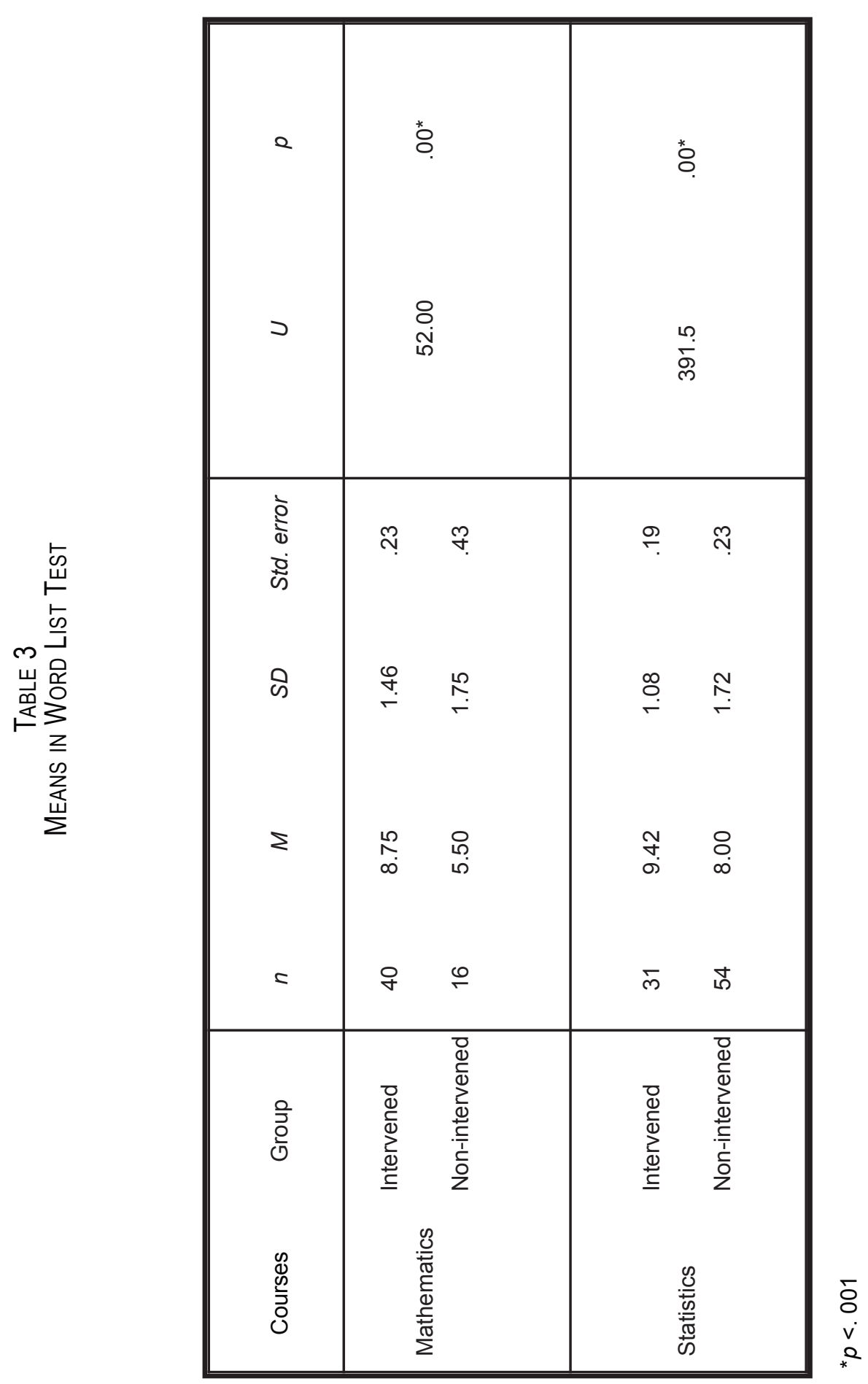


TABLE 4

AVERAge SCORES IN AI TEST

\begin{tabular}{|l|cccc|cc|}
\hline \multicolumn{1}{|c|}{ Group } & $n$ & $M$ & $S D$ & Std. error & $t$ & $p$ \\
\hline Intervened & 12 & 3.33 & .52 & .15 & & \\
Non-intervened & 12 & 2.92 & .42 & .12 & & $.04^{*}$ \\
& & & & & & \\
\hline
\end{tabular}

${ }^{*} p<.05$

GRAPHIC 1

MEAsuREMENTS OF THE RT BEFORE THE INTERVENTION

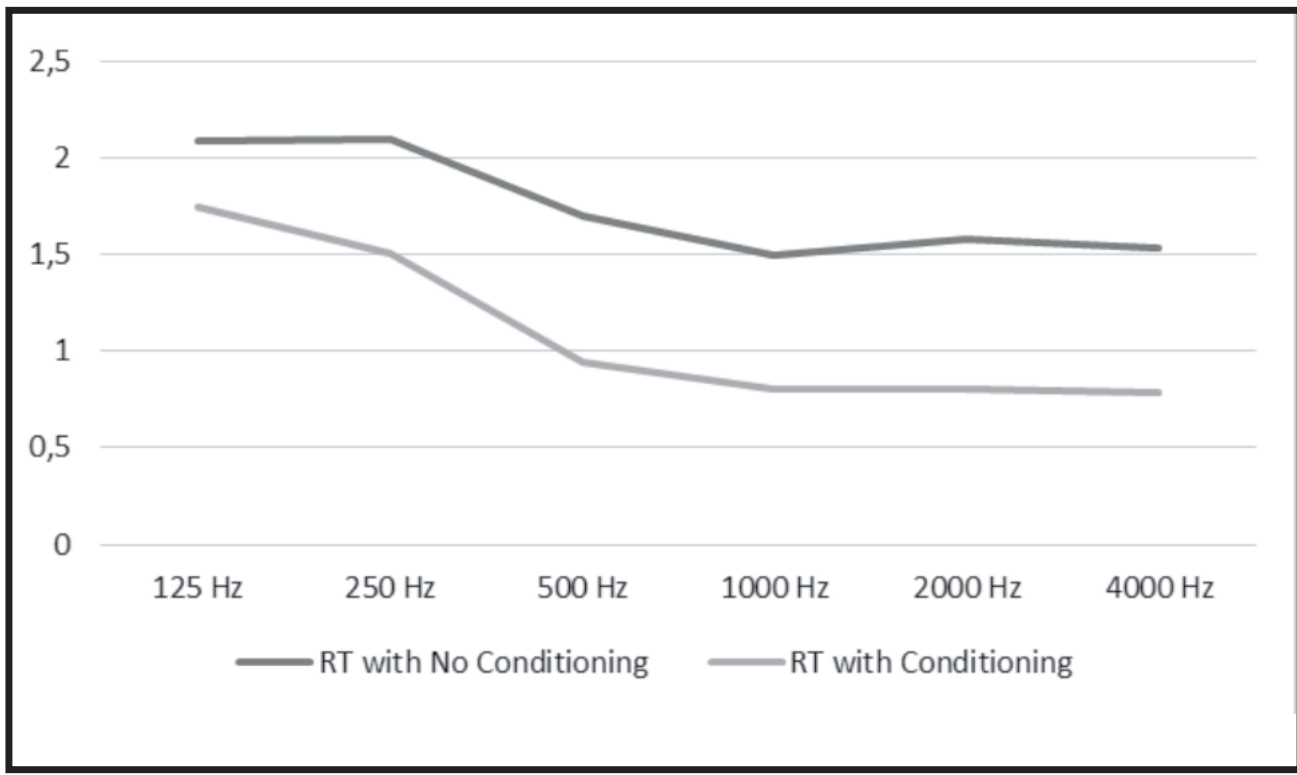


GRAPHIC 2

Differences in Word List Test between InterVened and Non-InterVened Groups

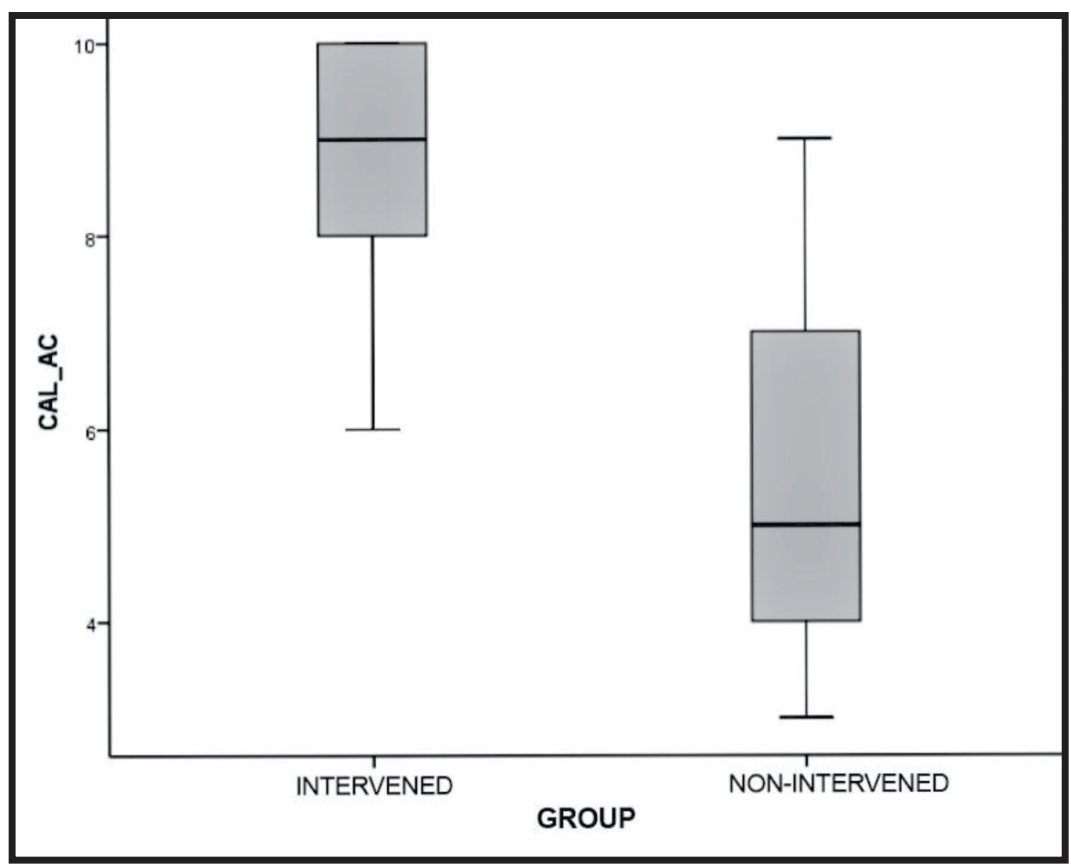

Source: Own construction

GRAPHIC 3

Differences betWeen InterVened and Non-INTERVEned Groups With the AI Strategy

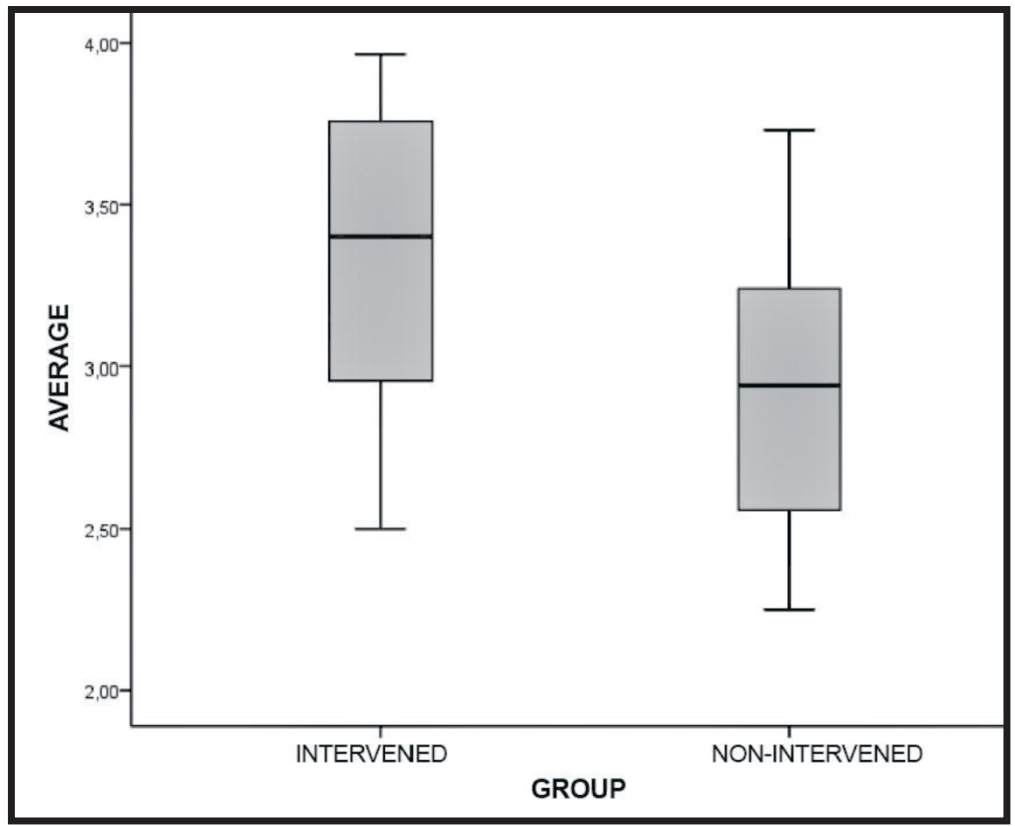

Source: Own construction 


\section{REFERENCES}

Añaños, E. (1999). Psicología de la atención y la percepción [Psychology of attention and perception]. Bellaterra: Universitat Autónoma de Barcelona.

Barkley, R.A. (1997). ADHD and the nature of self-control. Nueva York: Guilford Press.

Broadbent, D.E. (1954). The role of auditory localization in attention and memory span. Journal of Experimental Psychology, 47(3), 191-196. http://dx.doi.org/10.1037/h0054182

Bureau International D' Audiophonologie - BIAP. (2008). Recomendación BIAP 09/10-4. Inteligibilidad de la palabra en las aulas [Speech intelligibility in classrooms]. Extracted on september 22, 2013, from http://www.biap.org/bi apespagnol/esprecom094.htm

Cantor, L.C. \& Muñoz, A.I. (2009a). Salud vocal de docentes universitarios y condiciones acústicas en una universidad pública en Bogotá [Vocal health of university teachers and acoustic conditions in a public university in Bogotá]. Salud en el Trabajo, 17(2), 97-105.

Cantor, L.C. \& Muñoz, A.I. (2009b). Condiciones acústicas de las aulas universitarias en una universidad pública en Bogotá [Acoustics of the university classroom at a public university in Bogotá]. Medicina y Seguridad del Trabajo, 55(216), 26-34. http://dx.doi.org/10.4321/ S0465-546X2009000300004

De Esteban, A. (2003). Contaminación acústica y salud [Noise pollution and health]. Observatorio Medioambiental, 6, 73-95.

Dockrell, J.E. \& Shield, B. M. (2006). Acoustical barriers in classrooms: the impact of noise on performance in the classroom. British Educational Research Journal, 32(3), 509-525. http:// dx.doi.org/10.1080/01411920600635494

Escalona, E. (2006). Programa para la preservación de la voz en docentes de educación básica [Program for the preservation of voice teachers in basic education]. Revista Salud de los Trabajadores, 14(1), 31-49.
Estrada, C. \& Méndez, I. (2010). Impacto del ruido ambiental en estudiantes de educación primaria de la Ciudad de México [Impact of environmental noise in primary school students Mexico City]. Revista Latinoamericana de Medicina Conductual, 1(1), 57-68.

Flagg-Williams, J.B., Rubin, R.L., \& AquinoRussell, C.E. (2011). Classroom soundscape. Educational \& Child Psychology, 28(1), 89-99.

Gondim, M. \& Barreto, M. (2004). O estresse do professor acentuado pela precariedade das condições acústicas das salas de aula [The sharp teacher stress the precariousness of the acoustic conditions of classrooms]. Paper presented in the XXIV Encontro Nacional de Engenharia de Produção (ENEGEP). Florianópolis, SC, Brasil.

Hernández-Hernández, P. (1991). Psicología de la educación: Corrientes actuales y teorías aplicadas [Educational Psychology: Current trends and theories applied]. México: Trillas.

Instituto Colombiano de Normas Técnicas y Certificación - ICONTEC (2006). Planeamiento y diseño de instalaciones y ambientes escolares [Planning and design of facilities and school environments]. Bogotá, D.C.: Autor.

Instituto Nacional de la Infraestructura Física Educativa - INIFE (2011). Normas y especificaciones para estudios, proyectos, construcción e instalaciones [Standards and specifications for studies, projects, construction and facilities]. México, D.F.: Autor.

Irvine, L. \& Richards, R. (1998). Acoustics and noise control handbook for architects and builders. Melbourne: Krieger Pub Co.

Kennedy, S.M., Hodgson, M., Edgett, L.D., Lamb, N., \& Rempel, R. (2006). Subjective assessment of listening environments in university classrooms: Perceptions of student. Journal of the Acoustical Society of America, 119(1), 299309. http://dx.doi.org/10.1121/1.2139629

Klatte, M., Lachmann, T., \& Meis, M. (2010). Effects of noise and reverberation on speech perception and listening comprehension of 
children and adults in a classroom-like setting. Noise \& Health, 12(49), 270-282. http://dx. doi.org/10.4103/1463-1741.70506

Monteoliva, J.M., Ison, M.S. \& Pattini, A.E. (2014). Evaluación del desempeño atencional en niños: Eficacia, eficiencia y rendimiento [Attentional performance assessment in children: Effectiveness, efficiency and yield]. Interdisciplinaria, 31(2), 213-225. htttp://dx.doi.o $\mathrm{rg} / 10.1688$ 8/interd.2014.31.2.2

Möser, M., Zimmermann, S., \& Ellis, R. (2009). Engineering acoustics: An introduction to noise control. London: Springer.

Pérez, P. (2004). Las condiciones acústicas en las aulas de música [The acoustics conditions in classrooms music]. Revista de Psicodidáctica, 17, 137-145.

Puyuelo, M. \& Llinás, M. (1992). Problemas de voz en docentes [Voice problems in teachers]. Revista de Logopedia, Foniatría y Audiología, 12(2), 76-84.

Santalla, Z. \& Alvarado, J.M. (1999). ¿El ruido afecta la focalización de la atención visual? [Noise affects the focus of visual attention?]. Psicothema, 11(1), 97-111.

Santisteban, C. \& Santalla, Z. (1990). Efectos del ruido sobre memoria y atención [Noise effect on memory and attention]. Psicothema, 2, 4991.

Sato, H. \& Bradley, J. (2008). Evaluation of acoustical conditions for speech communication in working elementary school class- rooms. Journal of the Acoustical Society of America, 123 (4), 2064-2077. http://dx.doi.org/10.1121/1.2 839283

Shield, B. \& Dockrell, J. (2008). The effects of environmental and classroom noise on the academic attainments of primary school children. Journal of the Acoustical Society of America, 123(1), 133-144. http://dx.doi.org/ 10.1121/1.2812596

Szalma, J.L. \& Hancock, P. A. (2011). Noise effects on human performance: A meta-analytic synthesis. Psychological Bulletin, 137(4), 682707. http://dx.doi.org/10.1037/a0023987

Tejeda, P. (2001, Abril). Importancia de la voz en la profesión docente [Voice importance in the teaching profession]. Paper presented in the $\mathrm{V}$ Jornadas de Audición y Lenguaje. Madrid, España.

Weil, M. (2011). Listen Up! T H E Journal, 38(7), 16-19.

Wilson, C. (2005). Noise control: Measurement, analysis, and control of sound and vibration. London: Krieger Publishing Company.

Yang, W. \& Hodgson, M. (2007). Ceiling baffles and reflectors for controlling lecture-room sound for speech intelligibility. Journal of the Acoustical Society of America, 121(6), 35173526. http://dx.doi.org/10.1121/1.2730623

University Institution Politecnico Grancolombiano Bogotá - Colombia

Presented: april 27, 2015

Accepted: may 18, 2016 